\title{
PENYULUHAN PERAN PANGAN FUNGSIONAL DAN POLA HIDUP SEHAT UNTUK MENGHADAPI PANDEMI CORONA
}

\author{
Titri S. Mastuti ${ }^{1)}$, Intan C. Matita, Melanie Cornelia, W. Donald R. Pokatong, Aileen Neysha \\ Jurusan Teknologi Pangan, Fakultas Sains dan Teknologi, Universitas Pelita Harapan \\ Jl. Thamrin Boulevard 1100, Lippo Karawaci Tangerang 15811

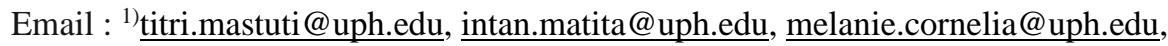 \\ wilbur.pokatong@uph.edu, aileen.widyapranata@uph.edu
}

\begin{abstract}
Abstrak
Pandemi global Coronavirus Disease-2019 (Covid-19) yang terjadi tahun 2020 disebabkan oleh virus corona jenis baru (SARS-COV2). Virus ini menyebabkan penyakit saluran pernafasan berat. Hingga saat ini belum ditemukan obat dan vaksin yang tepat untuk mengobati maupun mencegah penularan penyakit tersebut. Sistem imunitas atau daya tahan tubuh yang baik diyakini dapat membantu tubuh dalam melawan virus dan mempercepat kesembuhan. Salah satu cara meningkatkan daya tahan tubuh adalah dengan mengkonsumsi makanan bergizi dan pangan fungsional. Pangan fungsional bukan merupakan obat atau suplemen makanan namun mempunyai manfaat bagi kesehatan. Program Studi Teknologi Pangan tergerak untuk membagikan ilmu dan wawasan melalui kegiatan Pengabdian kepada Masyarakat dalam bentuk penyuluhan mengenai pangan fungsional dan penerapan hidup sehat dalam menghadapi situasi pandemi Covid-19 bagi komunitas Yayasan World Harvest di Tangerang. Penyuluhan dilakukan melalui online dengan aplikasi Zoom untuk meminimalkan penularan virus. Hasil kegiatan penyuluhan dapat dimengerti dan dipahami, masyarakat termotivasi untuk menerapkan dan meneruskan informasi mengenai hidup sehat salah satunya melalui konsumsi pangan fungsional.
\end{abstract}

Kata Kunci : pandemi covid-19, pangan fungsional, hidup sehat

\section{PENDAHULUAN}

Coronavirus Disease-2019 (Covid-19) adalah penyakit yang disebabkan oleh virus corona jenis baru (SARS-COV2) yang mulai terdeteksi sejak awal tahun 2020 di Wuhan, Cina. Virus ini menyebabkan penyakit saluran pernafasan berat dan mengakibatkan terjadinya pandemi global karena menyebar dengan cepat ke hampir seluruh negara di dunia dan mengakibatkan kematian jutaan orang di dunia (Yuliana, 2020). Hingga saat ini belum ditemukan obat atau vaksin untuk menangkalnya (Galanaki, 2020). Penularan virus Covid-19 dapat diminimalkan risiko penularannya dengan cara memakai masker, rajin mencuci tangan dan menghindari kontak serta tidak berada di wilayah penularan (Kominfo, 2020).

Imunitas tubuh yang baik diyakini dapat membantu tubuh dalam melawan virus dan mempercepat kesembuhan. Daya tahan tubuh dapat diperoleh dengan mengkonsumsi makanan sehat, bergizi dan lebih baik bila merupakan pangan fungsional (Haslberger, 2020). Selain itu menerapkan pola hidup sehat dalam hubungannya dengan pengolahan makanan sehari-hari juga dapat berkontribusi terhadap sistim imunitas manusia .

Berdasarkan fungsinya pangan dapat dikelompokkan menjadi tiga yaitu primer (memenuhi kebutuhan gizi), sekunder (memiliki penampilan dan cita rasa yang baik), dan tersier (memiliki fungsi fisiologis tertentu bagi tubuh)

$$
\text { Kesehatan dan Pangan }
$$


(Astawan, 2011). Pengembangan pangan fungsional dilatarbelakangi oleh fungsi tersier. Berdasarkan BPOM (2005), pangan fungsional merupakan pangan olahan yang mengandung satu atau lebih komponen fungsional yang berdasarkan kajian ilmiah mempunyai fungsi fisiologis tertentu, terbukti tidak membahayakan dan bermanfaat bagi kesehatan. Pangan fungsional bukan merupakan obat atau suplemen makanan karena dapat dikonsumsi tanpa dosis tertentu dan dapat dinikmati sebagaimana makanan pada umumnya (Goldberg, 1994). Komponen fungsional banyak terdapat pada makanan yang dikonsumsumsi sehari-hari seperti karetonoid pada wortel dan lycopen pada tomat (Novita, et al., 2015). Pangan fungsional juga dapat diperoleh dari produk pangan olahan seperti tempe, minuman beras kencur, sereal yang ditambah serat, mi instan yang diperkaya dengan vitamin dan mineral (Kusumayanti et al., 2016).

Salah satu media untuk menyampaikan informasi peran pangan fungsional dalam menghadapi pandemi Corona adalah guru-guru Sekolah Wahana Harapan Tangerang sebagai bagian dari Komunitas Yayasan World Harvest, Tangerang. Komunitas Yayasan World Harvest mempunyai kegiatan pemberdayaan masyarakat bidang sosial, ekonomi, pendidikan. Kegiatan yang dilakukan didasarkan pada potensi sumberdaya yang dimiliki dan pengembangannya, baik dalam bentuk penyuluhan, pendidikan dan atau pelatihan. Permasalahannya adalah guru-guru di Sekolah Wahana Harapan Tangerang belum mendapat banyak informasi tentang pola hidup sehat serta kaitan pangan fungsional dengan kesehatan dan imunitas tubuh untuk menghadapi pandemi Covid19. Oleh karena itu perlu dilakukan Penyuluhan Peran Pangan Fungsional dan Pola Hidup Sehat Untuk Menghadapi Pandemi Corona. Penyuluhan ini merupakan bentuk kepedulian kampus terhadap kesehatan masyarakat dan sebagai perwujudan salah satu Tridarma Perguruan Tinggi yaitu Kegiatan Pengabdian kepada Masyarakat(PkM).

\section{METODE}

Pelaksanaan PKM berupa penyuluhan yang dilakukan melalui virtual online. Media yang digunakan adalah melalui aplikasi Zoom. Kegiatan dilaksanakan pada hari Kamis 11 Juni 2020. Saat hari pelaksanaan, peserta diberi pemberitahuan yang berisi link untuk bergabung di dalam zoom penyuluhan PKM.

PKM berupa penyuluhan secara online dengan pembicara memaparkan materi dengan presentasi menggunakan slide Power Point. Setelah pemaparan dilanjutkan dengan diskusi tanya jawab dan pengisian evaluasi kegiatan menggunakan form kuesioner melalui google form. Pertanyaan evaluasi yang terdapat di dalam form kuesioner dapat dilihat pada Tabel 1.

\section{Tabel 1. Form Evaluasi PkM}

\begin{tabular}{l} 
1. Apakah Anda pernah mengikuti kegiatan \\
Pengabdian kepada Masyarakat (PKM) \\
sebelumnya? \\
a. Belum \\
b. Pernah \\
2. Apakah Anda dapat mengikuti kegiatan PkM \\
ini dengan baik? \\
a. Ya \\
b. Tidak \\
Apakah penyuluh dapat memberikan \\
informasi dengan baik? \\
a. Kurang \\
b. Cukup \\
c. Baik \\
Apakah media presentasi dapat dimengerti? \\
a. Kurang \\
b. Cukup \\
c. Mudah dimengerti \\
Apakah kegiatan PkM ini berguna bagi \\
Anda? \\
a. Ya \\
b. Tidak \\
Setelah kegiatan PkM ini selesai apakah \\
tindak lanjut Anda? (Jawaban boleh lebih \\
dari satu) \\
a. Termotivasi untuk menerapkan dalam \\
b. Meneruskan informasi kepada orang \\
selanjutnya : .................................... \\
\hline f. Tidak meneruskan informasi kepada \\
\hline .
\end{tabular}

\section{HASIL DAN PEMBAHASAN}

\section{Hasil dan Pelaksanaan Kegiatan}

Kegiatan PkM diikuti oleh 36 peserta dengan rincian 21 peserta merupakan guru dan kepala sekolah Wahana Harapan Tangerang, komunitas World Harvest, 9 peserta dari dosen di

$$
\text { Kesehatan dan Pangan }
$$


lingkungan Universitas Pelita Harapan, 6 orang dari tim PKM. Pelaksanaan kegiatan PkM dibagi menjadi dua sesi. Sesi pertama berupa penyuluhan atau penyampaian informasi mengenai pangan fungsional, cara hidup sehat dan kaitannya dengan situasi pandemi Covid-19. Sesi kedua merupakan sesi diskusi berupa tanya jawab antar peserta dan narasumber.

Materi penyuluhan disampaikan dalam bentuk slide presentasi Microsoft Power Point yang ditampilkan melalui fasilitas screen share di dalam aplikasi Zoom seperti dapat dilihat pada Gambar 1. Materi yang disampaikan meliputi pemaparan mengenai pandemi Covid-19 atau Corona dan bahayanya, pengenalan mengenai pangan fungsional dan contoh-contohnya dalam menu sehari-hari, cara hidup sehat melalui pemilihan bahan pangan sesuai gizi seimbang serta cara pengolahan dan penanganan pangan yang tepat.
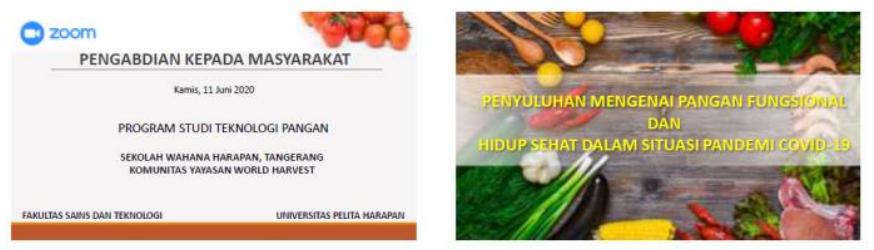

Gambar 1. Materi penyuluhan PkM

Peserta dapat mengikuti kegiatan $\mathrm{PkM}$ dengan baik. Peserta antusias dan menyimak pemaparan materi oleh tim penyuluhan dengan seksama. Setelah selesai materi disampaikan, acara dilanjutkan dengan sesi kedua yaitu diskusi tanya jawab. Peserta aktif terlibat dalam sesi ini dengan mengajukan beberapa pertanyaan dan dijawab dengan baik oleh tim PkM. Beberapa foto saat kegiatan PkM berlangsung dapat dilihat pada Gambar 2.

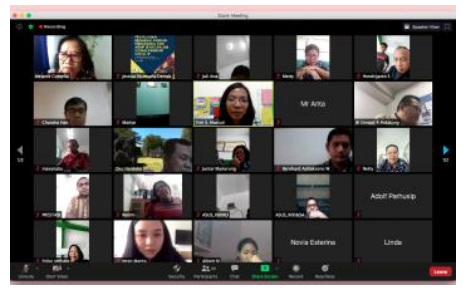

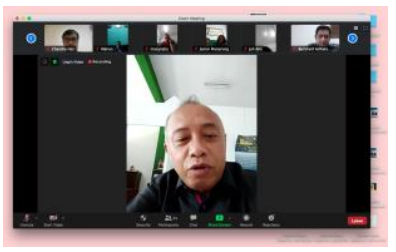

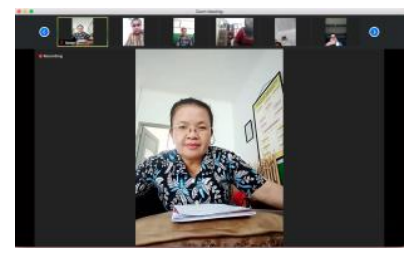

Gambar 2. Foto kegiatan PkM secara online

Pandemi Corona atau Covid-19 dapat terjadi karena penularan virus yang demikian cepat. Virus SARS-COV2 menyerang saluran pernafasan dan mudah menular. Virus tersebut dapat bertahan lama di permukaan benda namun dapat di-inaktivasi oleh panas dan sanitaiser dan pencucian menggunakan sabun dan air mengalir (Kampf et al., 2020). Pencegahan penularan dapat dilakukan dengan penggunaan masker dan rajin mencuci tangan (Kominfo, 2020). Pencegahan penularan dapat juga dilakukan dengan meningkatkan imunitas tubuh yaitu dengan konsumsi makanan bergizi dan sumber pangan fungsional (Haslberger, 2020).

Komponen pangan fungsional banyak terdapat pada bahan makanan seperti vitamin C, likopen, karetonoid, kurkumin. Kurkumin diketahui memiliki aktivitas antivirus dan banyak ditemukan pada kunyit yang dapat digunakan sebagai minuman maupun bahan masakan (Matthew dan Hsu, 2018). Kandungan senyawa pada bahan pangan dapat berfungsi sebagai antivirus, antibakteri, antioksidan, antikanker. Namun komponen tersebut juga mudah terdegradasi bila cara pengolahan tidak tepat seperti penggunaan suhu pemasakan yang tinggi dan lama (Igwemmar et al., 2013) sehingga menjadi berkurang nilai gizi dan aktivitas fungsionalnya. Dengan demikian melalui PKM ini dapat mengedukasi masyarakat mengenai sumber pangan fungsional dan cara pengolahan yang tepat agar dapat mempertahankan komponen senyawa aktifnya sehingga dapat dimanfaatkan untuk kesehatan dan meningkatkan imunitas dalam menghadapi pandemi Corona (Covid-19). Beberapa cara pengolahan bahan pangan dapat dilihat pada Gambar 3. 


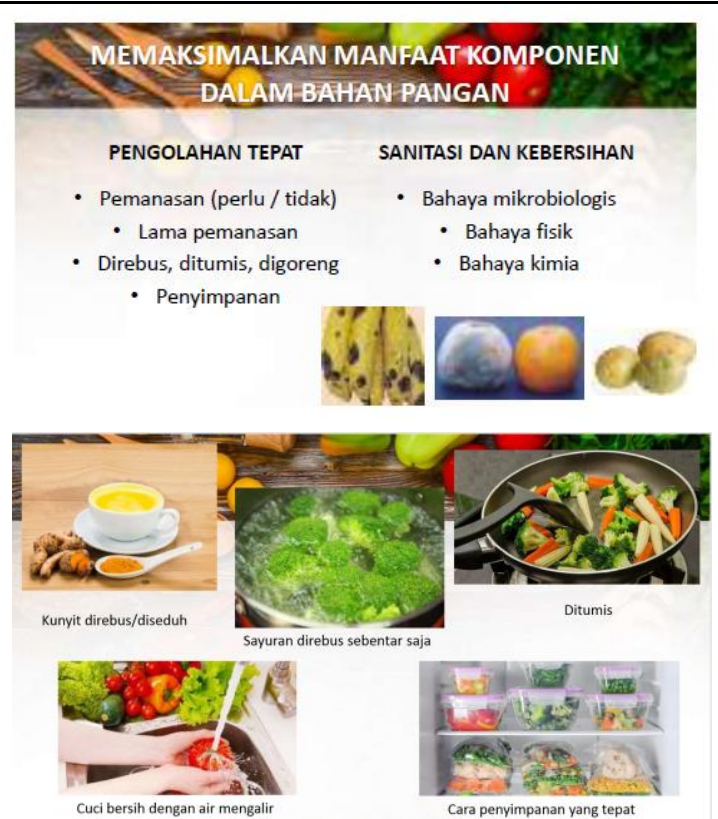

Gambar 3. Materi penyuluhan pengolahan bahan pangan

Penyuluhan yang diberikan pada PkM ini juga menggarisbawahi bahwa meningkatkan imunitas tubuh bukan bergantung pada konsumsi makanan yang banyak namun juga tergantung pada pola hidup sehat. Pola hidup sehat ini dapat mencakup apa yang dimakan, bagaimana cara pengolahannya, berapa banyak yang dimakan dan keseimbangan dengan aktivitas sehari-hari. Hal ini dapat dilihat pada slide penyampaian materi seperti di dalam Gambar 4.

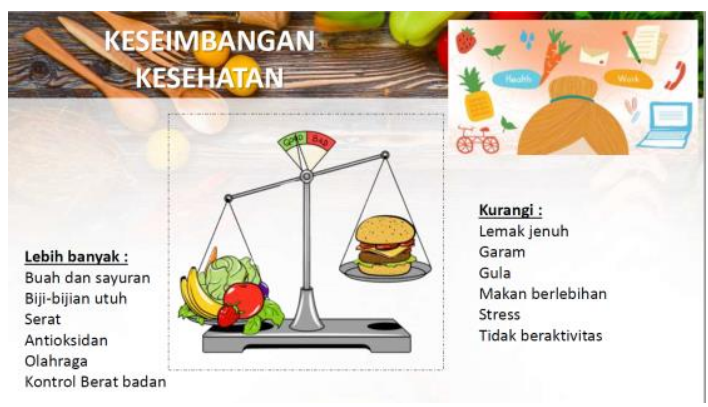

Gambar 4. Materi penyuluhan pola hidup sehat

\section{Hasil Evaluasi Kegiatan}

Evaluasi kegiatan PkM dilakukan dengan meminta peserta mengisi form kuesioner yang diberikan melalui link google form. Evaluasi diperlukan untuk mengetahui apakah penyuluhan yang disampaikan dapat diterima dengan baik oleh peserta. Hasil evaluasi dapat dilihat pada Tabel 2.
Berdasarkan hasil evaluasi pada Tabel 2, terlihat bahwa peserta PKM memberikan respon positif terhadap pelaksanaan kegiatan PKM yang dilakukan melalui penyuluhan secara online. Berdasarkan analisis hasil kuesioner diketahui bahwa rata-rata peserta sudah pernah mengikuti kegiatan penyuluhan $\mathrm{PkM}(61,9 \%)$. Hampir seluruh peserta $(95,2 \%)$ dapat mengikuti kegiatan dengan baik. Meskipun kegiatan PkM diadakan melalui daring fasilitas Zoom, penyampaian materi dapat diterima dengan baik peserta. Hal ini terlihat dari jawaban kuesioner yang menyatakan bahwa materi dan media presentasi mudah dimengerti $(85,7 \%)$, penyuluh memberikan informasi dengan baik $(71,4 \%)$ dan $100 \%$ peserta menyatakan bahwa kegiatan PkM ini berguna bagi mereka.

Tabel 2. Hasil Evaluasi Pelaksanaan PkM

\begin{tabular}{|c|c|c|}
\hline No & Jenis Jawaban & $\begin{array}{l}\text { Persentase } \\
\text { Jawaban } \\
(\%) \\
\end{array}$ \\
\hline \multirow[t]{2}{*}{1} & Belum & 38,1 \\
\hline & Pernah & 61,9 \\
\hline \multirow[t]{2}{*}{2} & Ya & 95,2 \\
\hline & Tidak & 4,8 \\
\hline \multirow[t]{3}{*}{3} & Kurang & - \\
\hline & Cukup & 28,6 \\
\hline & Baik & 71,4 \\
\hline \multirow[t]{3}{*}{4} & Kurang & - \\
\hline & Cukup & 14,3 \\
\hline & Mudah dimengerti & 85,7 \\
\hline \multirow[t]{2}{*}{5} & Ya & 100 \\
\hline & Tidak & - \\
\hline \multirow[t]{3}{*}{6} & \begin{tabular}{ll}
\multicolumn{1}{c}{ a.Termotivasi } & untuk \\
menerapkan & dalam \\
rutinitas harian &
\end{tabular} & 66,7 \\
\hline & \begin{tabular}{lr}
\multicolumn{1}{c}{ b. } & Meneruskan \\
informasi & kepada \\
lain &
\end{tabular} & 76,2 \\
\hline & $\begin{array}{l}\text { c. Tidak meneruskan } \\
\text { informasi kepada orang } \\
\text { lain }\end{array}$ & - \\
\hline
\end{tabular}

Berdasarkan evaluasi juga dapat dilihat bahwa $66,7 \%$ peserta termotivasi untuk menerapkan dalam rutinitas harian dan76,2\% peserta berniat 
meneruskan informasi yang diperoleh dari kegiatan PkM kepada orang lain.

Peserta PkM juga berperanserta dengan memberi saran untuk keberlangsungan kegiatan PkM di waktu mendatang. Saran yang diberikan oleh peserta antara lain untuk mengadakan kegiatan PkM dengan topik mengenai cara menyimpan bahan pangan agar tahan lama dan tetap mempertahankan kandungan gizinya di masa pandemi serta topik pengolahan produk pangan dan keamanan pangan.

Hasil kuesioner ini menunjukkan bahwa kegiatan PKM dalam bentuk penyuluhan sangat berguna bagi para peserta dan dapat dilakukan lagi di kemudian hari, tetapi dengan topik yang lain. Model PKM ini dapat dilakukan untuk meningkatkan kepedulian masyarakat terhadap pentingnya pangan bagi kesehatan terutama dalam menghadapi pandemi penularan penyakit berbahaya.

\section{KESIMPULAN}

Kegiatan PkM berupa penyuluhan terhadap guru-guru Sekolah Wahana Harapan Tangerang, komunitas Yayasan World Harvest dilakukan secara online dan diikuti oleh 36 peserta dengan antusiasme dan partisipasi aktif dari peserta.

Penyuluhan mengenai peran pangan fungsional dan penerapan pola hidup sehat dalam situasi pandemi Corona dapat diterima dan dimengerti dengan baik oleh peserta penyuluhan.

\section{SARAN}

Masyarakat perlu untuk terus dimotivasi dan didorong agar dapat menggunakan pangan fungsional dan menerapkan hidup sehat kaitannya dengan meningkatkan imunitas tubuh. Salah satu caranya adalah dengan mengadakan kegiatan penyuluhan $\mathrm{PkM}$ berkesinambungan kepada kelompok masyarakat.

\section{UCAPAN TERIMAKASIH}

Ucapan terimakasih disampaikan kepada LPPM UPH yang telah mendanai pelaksanaan PKM ini dengan nomor PKM : PM-026-FaST/I/2020.

\section{REFERENSI}

Astawan, M. 2011. Pangan Fungsional untuk Kesehatan yang Optimal. Fakultas Teknologi Pertanian, Bogor.

[BPOM] Badan Pengawas Obat dan Makanan. 2005. Peraturan Kepala Badan Pengawas Obat dan Makanan Republik Indonesia Nomor HK. 00.05.52.0685 tahun 2005 tentang Ketentuan Pokok Pengawasan Pangan Fungsional. Jakarta : BPOM.

Galanaki, C.M. 2020. The Food Systems in the Era of the Coronavirus(COVID-19) Pandemic Crisis : perspective. Foods, $9: 523$.

Goldberg. I. 1994. Functional Foods: Designer Foods, Pharmafoods, Nutraceuticals. Chapman \& Hall. New York.

Haslberger, A.G., Jacob, U., Hippe, B., Karlic, H. 2020. Mechanisms of selected functional foods against viral infections with a view on COVID-19: Mini review. Functional Foods in Health and Disease, 5(10):195-209.

Igwemmar, N.C., Kolawole, S.A., Imran, I.A. 2013. Effect Of Heating On Vitamin C Content Of Some Selected Vegetables. IJSTR, 2(11) : 209212.

Kampf, G., Voss, A., Scheithauer, S. 2020. Inactivation of coronaviruses by heat : Letter to the Editor. J Hosp Infect, 105 (2) : 348-349.

Kominfo. 2020. Panduan Menanggulangi Covid-19 untuk Pribadi, Keluarga dan Komunitas. https://covid19.patikab.go.id/v3/download/Fokus_L indungi_Diri.pdf

Kusumayanti, H., Mahendrajaya, R.H., Hanindito, S.B. 2016. Pangan fungsional dari tanaman lokal Indonesia. Metana, 12(1):26-30.

Mathew, D., Hsu, W. L. 2018. Antiviral potential of curcumin. Journal of functional foods, 40 : 692-699.

Novita, M., Satriana, Hasmarita, E. 2015. Kandungan Likopen dan Karetenoid Buah Tomat (Lycopersicum pyriforme) Pada Berbagai Tingkat Kematangan: Pengaruh Pelapisan dengan Kitosan

$$
\text { Kesehatan dan Pangan }
$$


dan Penyimpanan. Jurnal Teknologi dan Industri

Pertanian Indonesia, 7(1): 35-39.

Yuliana. 2020. Corona virus diseases

(Covid-19) : Sebuah tinjauan literatur. Welness and

Healthy Magazine, 2(1) : 187-192. 